It appears therefore that some doubt still exists as to whether the simple gas hydrates, formed in twocomponent systems, do in fact present large deviations from the ideal stoicheiometry or exhibit significant changes of $n$ along the saturation lines, except perhaps in the special case when the hydrate-former volume is near the upper limiting size for its lattice cavities, as for example ethane, methyl bromide and bromine in lattice structure I.

Contribution No. 21, Exploratory Research Laboratory, Dow Chemical of Canada, Ltd., Sarnia, Ontario. May 4.

1 van der Waals, J. H., and Platteeuw, J. C., Nature, 183, 462 (1959). Barrer, R. M., ibid, 183, 463 (1959)

. 36, 359 (1949). Scheffer, F. E. C., and Meyer, G., Verslag. Akad. wetenschap., Amsterdam, 27, 1104, 1305

(1919), W. M., and Frost, E. M., jun., "Gas Hydrates and Their Relation to the Operation of Natural-Gas Pipe Lines", U.S. Bureau of Mines Monograph, 8, 27 (1946).

\section{Supercooling of Water Droplets}

As part of a research programme designed to study the kinetics of nucleation in solutions of electrolytes, I have made some observations on the supercooling of water droplets in the form of water in oil emulsions stabilized by a number of $W / O$ emulsifying agents.

The procedure adopted was to disperse the water in 'Nujol' oil containing about 5 per cent of the emulsifying agent. In this way particles which catalyse the nucleation of the water can be isolated in individual droplets, thus reducing their effect to negligible proportions. This method has been previously used in the study of the solidification of molten metals'. The emulsions which resulted contained a distribution of particle sizes with a sharp maximum in the region $2-4 \mu$. The solidification of the water was followed dilatometrically and indicated by a rapid increase in the volume of the emulsion at some well-defined temperature. The rate of cooling in the experiments was $\sim 0.15 \mathrm{deg} . / \mathrm{min}$.

\begin{tabular}{|c|c|c|c|c|c|}
\hline Emulsifier & $\begin{array}{l}\text { Nucleation } \\
\text { temperature } \\
\text { (deg. K.) }\end{array}$ & $\begin{array}{l}\text { Supercooling } \\
\text { (deg. C.) }\end{array}$ & $\begin{array}{l}\sigma_{\text {homo }} \\
\text { (ergs. cm.-2) }\end{array}$ & $\theta$ & $\boldsymbol{K}_{8}$ \\
\hline Lanolin & $257 \cdot 5$ & 15.5 & 16.5 & 84 & 480 \\
\hline $\begin{array}{l}\text { Sorbitan } \\
\text { monoleate }\end{array}$ & $261 \cdot 0$ & $12 \cdot 0$ & $14 \cdot 0$ & 68 & 635 \\
\hline $\begin{array}{l}\text { Sorbitan } \\
\text { trioleate }\end{array}$ & 259.5 & 13.5 & $15 \cdot 1$ & 74 & 590 \\
\hline Sorbitan & & & & & \\
\hline sesquoileate & $260 \cdot 0$ & $13 \cdot 0$ & $14 \cdot 7$ & 72 & \\
\hline Soymul A.B. & $259 \cdot 5$ & $13 \cdot 5$ & $15 \cdot 1$ & 74 & 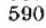 \\
\hline
\end{tabular}

In these experiments much smaller degrees of supercooling were observed than previously reported by other workers's. This I attribute to the formation of ice crystals on the inside surface of the droplets and catalysed by this surface. Since it is reasonable to suppose that molecules of emulsifying agent adsorbed on the droplet surface should not show any long-range order or 'crystallinity', this catalytic effect cannot be attributed to epitaxial growth on the droplet surface as is the case with the seeding of ice crystals by silver iodide. There is not sufficient evidence to say why the ice forms at the surface (heterogeneous nucleation) instead of in the bulk of the droplet (homogeneous nucleation), but the electrical charges which reside at the surface of the droplet and are presumably responsible to some extent for the stability of the emulsion, may also play some part in the catalytic activity of the surface.
From the nucleation theories of Volmer and by assuming that the nucleus forms as a spherical cap on the inside of the droplet, I have estimated values for the angle of contact $\theta$, between the critical ice nucleus and the surface of the droplet and also the number of molecules $K_{s}$, in this critical nucleus (Table 1 ). Values for the interfacial energies $\sigma_{\text {homo }}$, are interpolated from the results of Jacobi ${ }^{3}$.

My thanks are due to Dr. P. Sherman of the Gestetner Co., London, for information concerning the emulsifying agents.

Department of Chemistry,

P. G. Fox

The University,

Bristol 8.

May 15.

* Present address: Department of Chemistry, Princeton University, New Jersey.

${ }^{1}$ Vonnegut, B., J. Colloid Sci., 3, 563 (1948). Turnbull, J. Chem. Phys.,

20, 411 (1952). (1955). Mason, B. J., Nature, 181, $382(1958)$

s Jacobi, w., $Z$. Naturf., 10, a, 322 (1955).

\section{BIOCHEMISTRY}

\section{Extraction of the Total Protein from Wheaten Flour in the Form of Soluble Derivatives}

SwaN ${ }^{1}$ has recently developed a method for solubilizing keratins which depends on the fission of cystine disulphide bonds by reaction with cupric and sulphite ions, with the formation of S-sulpho cysteine residues. The protein when modified in this way becomes water-soluble, with amino-acid residues other than cysteine and cystine unchanged. Swan's method has been applied by Pechère, Dixon, Maybury and Neurath ${ }^{2}$ to trypsinogen and chymotrypsinogen, and in these cases also the resulting $\mathrm{S}$-sulpho derivatives were water-soluble.

We have found that when Swan's method is applied to white flour (approximately 70 per cent extraction) the protein is readily dissolved. Most of the starch remains as an insoluble residue which may be separated by centrifugation from the clear solution containing the protein derivatives; less than 3 per cent of the carbohydrate is solubilized with the protein, and this includes pentosan material. Table 1 giving the nitro-

\begin{tabular}{lcccc}
\multicolumn{5}{c}{ Table 1 } \\
$\begin{array}{l}\text { Wheat } \\
\begin{array}{c}\text { Nitrogen in flour (per } \\
\text { cent) }\end{array}\end{array}$ Manitoba & Svenno & Bersee & Hybria 45 \\
$\begin{array}{c}\text { Nitrogen in residue } \\
\text { (per cent) }\end{array}$ & 2.31 & 2.47 & 2.11 & 1.63 \\
& 0.03 & 0.03 & 0.06 & 0.04
\end{tabular}

$10 \mathrm{gm}$. defatted flour extracted at room temperature for $1-2 \mathrm{hr}$. with $125 \mathrm{ml}$. of reagent essentially similar to that described by Swan. The successively with 0.1 $\boldsymbol{M}$ ammonia, water, 1 per cent acetic acid, water.

gen content of the insoluble residue, shows, for flours derived from different wheats, that the extraction of protein is virtually complete.

The solution containing the protein may be freed from copper after removal of excess reagents by dialysis against $0 \cdot 1 \quad M$ ammonia by dialysis against ethylenediaminetetraacetate in $0 \cdot 1 \quad M$ ammonia or against $0.1 M$ hydrochloric acid. The solubility of the protein derivatives is extremely sensitive to $p H$. The solutions are clear at $p H 7 \cdot 5-8 \cdot 0$ but, in the presence of McIlwaine's buffer, precipitation occurs at $p \mathrm{H} \quad 7 \cdot 0$ and increases to a maximum at about $p H 4.0$. 